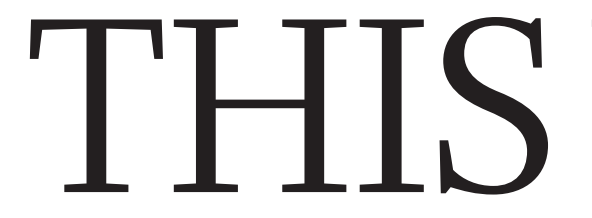

EDITORIALS
WORLD VIEW The researchers who warned last year about East African droughts p.7
HIV TEST New assay could speed screening in remote and rural areas $\mathbf{p . 8}$
HEAR HEAR Rainforest

vine uses echo chamber

to lure pollinating bats $\mathbf{p . 8}$

\title{
Staying at home
}

\author{
China's best young scientists are working abroad. The country is trying to change that - and \\ when it succeeds, the results will be startling.
}

$\mathrm{T}$ The postdoctoral researcher is the workhorse of laboratories around the world, and principal investigators in countries ranging from the United States to Singapore have come to depend for their postdocs on well educated and hard-working researchers from China. Yet, ask senior scientists in China, especially bioscientists with experience of working overseas, and they'll say they want and need more postdocs back home - assuming that they have any at all.

Almost all the best young Chinese scientists with new $\mathrm{PhDs}$ choose to spend the formative period of their training for an independent career abroad. And those Chinese postdocs who do choose to work in China often desert academia for more lucrative careers in biotechnology, the pharmaceutical industry or contract research. The upshot is that, to get any work done, Chinese academic scientists have to keep training new groups of graduate students to fill the gap.

No doubt this is part of the reason that researchers in China, despite their reputation for hard work and putting in long hours, and despite the country's increasing investment in science, look extremely unproductive by international standards (see News Feature, page 22). One Chinese scientist described it as the ambitious nation shooting itself in the foot, twice - spending time and resources to train students and then sending them abroad to work for a competitor.

Yet the current system leaves talented people little choice but to leave. In particular, established laboratories overseas have more experience and success in producing good publications, which help to secure jobs for their postdocs. These laboratories are often better equipped than in China, and a postdoc job in the United States or Europe pays as well as or better than a more senior principal-investigator position in China.
And even while senior staff at Chinese universities and institutes despair of finding good-quality postdocs, they know that when a fulltime post comes up, it will probably go to someone who has spent time abroad. A mediocre CV that includes stints in the United States or another foreign country, time and again trumps solid publications based on work done locally (see Nature 457, 522; 2009). The lesson is clear - if you want to make it in China, go and train somewhere else.

But the tide may be turning. The Institute of Neuroscience in Shanghai (see page 22) together with institutions in Beijing such as the National Institute of Biological Sciences, the Institute of Biophysics, Tsinghua University and Peking University, are starting to form a critical mass - a domestic ring of excellence that offers the high-quality start to an independent career that students have up to now been forced to seek elsewhere.

Over the next few years, the effect could be hugely significant. With the US economy failing and some top institutes in China already considering ways to increase postdocs' salaries, benefits could start to converge. New facilities in China are as good as, or better than, in the West, and research in China offers other attractions, including easier access to primates. Research pastures at home will start to look as green as those abroad.

New recruits to the Chinese army of $\mathrm{PhDs}$ would do well to consider their country's own facilities as career launchpads. And Chinese institutions can do their part by looking seriously at domestically bred talent when recruiting, rather than running after returnees. Once that mentality starts to change, and Chinese laboratories fill up with four or five postdocs each, those productivity figures will shift rapidly.

\section{Safe, not secure}

\section{A legal victory for US stem-cell research will not end the uncertainty over this disputed field.}

W hen US district court judge Royce Lamberth last week threw out a 2009 lawsuit against federally funded research on human embryonic stem cells, he concluded that Congress has acted reasonably in supporting the work. It matters little that Lamberth made clear he was only grudgingly falling into line with a higher court's decision in April — he was right.

This reading of the law does not, and will never, satisfy those who see the work as unethical. But six successive, elected Congresses have seen fit to fund the research, and what began as a US\$10-million investment by the National Institutes of Health (NIH) in 2002 has grown to an estimated $\$ 125$ million this year.
Lamberth's judgment (see page 14) significantly diminished the chances of his decision being reversed on appeal by higher courts. Scientists who take NIH funds for this research can breathe a large, if not total, sigh of relief when it comes to legal challenges.

Still, it must be acknowledged that the lawsuit - and the decade of politics around stem cells that preceded it - has inflicted serious damage on the field. From one year to the next, and sometimes one month or day to the next, stem-cell researchers have not been able to count on reasonable and steady government funding. Stem-cell scientists interviewed last week were notably cool on the new ruling. For many, it is irrelevant, because they have moved to politically safe and scientifically exciting work with induced pluripotent stem cells. Others have retreated to using adult stem cells.

It is unknown how many young people have shunned careers in the field because of the uncertainty, but is likely to be a considerable number. Those established embryonic stem-cell scientists who have funding from private or state grants continue with the work, but even now many of them consider NIH funding to be unreliable given its volatile political profile. The law has got this one right, but being right is rarely enough. 